\title{
Clinical Studies Investigating the Use of Leuprorelin in Breast Cancer Patients from Asia
}

\author{
Wonshik Han ${ }^{1 *}$, Hyun Jo Youn ${ }^{2}$
}

\begin{abstract}
Leuprorelin is a synthetic analogue of naturally occurring gonadotropin-releasing hormone. It is currently approved in the United States, Europe and Asia and has indications in advanced prostate cancer, endometriosis, breast cancer and precocious puberty. This review examined clinical trials of leuprorelin in women with breast cancer in Asia. Methods: Four studies were identified, involving 999 premenopausal females with breast cancer. Leuprorelin was administered subcutaneously at doses of $3.75 \mathrm{mg}$ every 4 weeks, $11.25 \mathrm{mg}$ every 12 weeks or $22.5 \mathrm{mg}$ every 24 weeks in addition to either adjuvant chemotherapy or hormonal therapy. Results: Leuprorelin was shown to preserve ovarian function, reduce symptoms of ovarian failure, the occurrence of early menopause, and the time to resumption of menses. Leuprorelin-related adverse events included hot flush, mood swings and urogenital symptoms. Conclusion: Clinical studies in breast cancer patients from Asia have primarily investigated the effect of leuprorelin on the protection of ovarian function in patients who receive chemotherapy, assessed the ability of leuprorelin to suppress serum estradiol to menopausal levels, or to determine the efficacy and safety of leuprorelin in daily medical practice.
\end{abstract}

Keywords: Breast neoplasms- menopause- premenopause- leuprolide- fertility

Asian Pac J Cancer Prev, 20 (5), 1475-1479

\section{Introduction}

The incidence of breast cancer is about $10 \%$ for most regions of the world, (Asthana et al., 2014) and appears to be increasing in Asian regions (Ataya et al., 1995; ClinicalTrials.gov, 2017). Increases in incidence may reflect better screening and detection. Despite mortality from breast cancer decreasing in some regions in Asia,6 others have reported an increase in mortality, Ataya et al., (1995) suggesting that treatment may not be optimal in some regions.

Approximately $15 \%$ of breast cancers are diagnosed in patients of reproductive age (GLOBOCAN, 2016). Unfortunately, treatment with adjuvant systemic chemotherapy, particularly cyclophosphamide based therapy, while offering the promise of improved survival, comes at the cost of premature ovarian failure (GLOBOCAN, 2016). Leuprorelin is a synthetic analogue of naturally occurring gonadotropin-releasing hormone $(\mathrm{GnRH})$, which acts as a potent inhibitor of pituitary gonadotropin secretion when given continuously at therapeutic doses. Leuprorelin is approved for the treatment of hormone-dependent diseases, including advanced prostate cancer, endometriosis, breast cancer and precocious puberty. In humans, administration of leuprorelin results in an initial increase in circulating levels of luteinizing hormone (LH) and follicle-stimulating hormone (FSH), leading to a transient increase in levels of the gonadal steroids (testosterone and dihydrotestosterone in males, and estrone and estradiol [E2] in premenopausal females). However, continuous administration of leuprorelin results in decreased levels of $\mathrm{LH}$ and $\mathrm{FSH}$, usually within 2 to 4 weeks from initiation of treatment. Cessation of $\mathrm{GnRH}$ leads to resumption of normal ovarian function. Leuprorelin has been used to protect the ovaries against chemotherapy-induced toxicity (Kim et al., 2014; Kurebayashi et al., 2017).

\section{Materials and Methods}

Leuprorelin is approved for the treatment of hormone-dependent diseases, including advanced prostate cancer, endometriosis, breast cancer and precocious puberty. It is currently approved for use in the United States, Europe and Asia, and can be administered every 4, 12 or 24 weeks, although approved formulations and indications vary.

In September 2015, leuprorelin $22.5 \mathrm{mg}$ subcutaneous injection became the world's first product to obtain approval for the treatment of premenopausal breast cancer 
as a 24-week depot, it gained approval in Japan following the results of two Phase III, multicenter, randomized, open-label clinical studies (Lambertini et al., 2015; Park et al., 2010).

The purpose of this review is to examine how leuprorelin is being investigated for the treatment of patients with breast cancer in Asia and to investigate outcomes experienced by these patients following treatment with leuprorelin. Searches were conducted in PubMed, the Cochrane library and clincialtrials.gov. Articles were included if they were published in English between 1 January 2000 and 31 December 2016. Eligible studies were Phase I-IV and included Asian women with breast cancer who had been treated with leuprorelin . Study eligibility assessment was performed in a manual, non-blinded manner by a single person. Studies retrieved using the search criteria with an abstract available for review were screened against the eligibility criteria described above. Studies with no abstract to review and congress abstracts were excluded. Studies were also excluded if their abstract did not mention 'leuprolide' and 'breast cancer', or one of their associated MeSH Entry Terms (UK or US spelling). Finally, full-text articles of the remaining studies were screened against the remaining eligibility criteria and included in the final analysis if they were still eligible.

Regarding the requirement for studies including participants from Asia, studies were only included if they reported data from countries within Southeastern Asia, Far East Asia, or Western Asia excluding the Middle East; the PubMed MeSH Term for Asia was referred to for country categorization.

\section{Results}

Of 55 identified studies, four studies were included, involving 999 analyzed patients. All participants were premenopausal females with a prior diagnosis of breast cancer (Table 1). Exclusion criteria in relation to prior chemotherapy or hormonal therapy varied between the studies (GLOBOCAN, 2016; Lambertini et al., 2015; Recchia et al., 2015). Leuprorelin was administered as a subcutaneous injection in each of the four studies, and was administered at $3.75 \mathrm{mg}$ every 4 weeks, $11.25 \mathrm{mg}$ every 12 weeks, or $22.5 \mathrm{mg}$ every 24 weeks. In each study, leuprorelin was administered with either adjuvant chemotherapy or hormonal therapy. Only one study had a comparator arm, in which leuprorelin $3.75 \mathrm{mg}$ given every 4 weeks in addition to cyclophosphamide-doxorubicinbased chemotherapy was compared with the chemotherapy regimen alone. Primary study outcomes were protection of ovarian function, number of participants reporting one or more adverse drug reactions, or percentage of participants with a suppressive effect of leuprorelin on serum estradiol to menopausal levels.

Protection of ovarian function and resumption of menses

A single randomized controlled trial comparing chemotherapy alone and chemotherapy plus leuprorelin was conducted in pre-menopausal Chinese women with stage I to III breast cancer (Recchia et al., 2015) (Table 1).
Compared to chemotherapy alone, patients administered leuprorelin were more likely to resume normal menses within 12-months of chemotherapy (GLOBOCAN, 2016). In an open-label study, $62 \%$ and $82 \%$ of patients experienced resumed menses within six-months and three-years post-chemotherapy, respectively (Recchia et al., 2015). Two patients in the open label study became pregnant within one year post-chemotherapy. One gave birth to a healthy infant, in the other, the pregnancy was terminated (no reason was given) (Recchia et al., 2015).

\section{Early menopause}

Leuprorelin was shown to effectively preserve ovarian function after chemotherapy, with $28.7 \%$ of women in the chemotherapy alone arm, and $16.9 \%$ of women in the leuprorelin-chemotherapy arm experiencing early menopause $(\mathrm{p}<0.01)$ (GLOBOCAN, 2016). Women receiving cyclophosphamide-doxorubicin with a taxane were less likely to experience premature menopause (GLOBOCAN, 2016).In an open-label study, no patients exhibited menopausal symptoms following leuprorelin use (GLOBOCAN, 2016).

\section{Gonadotrophin levels}

Leuprorelin can reduce E2 levels to menopausal levels.10, 11 Mean values of E2 are significantly decreased following chemotherapy regardless of leuprorelin use (GLOBOCAN, 2016). Mean values of FSH are significantly increased, however, values in patients receiving chemotherapy alone are higher than those in women receiving concomitant leurprorelin (GLOBOCAN, 2016). In a single arm study from Korea, increases in FSH and LH peak at 3-months post chemotherapy, and return to baseline levels by six months (Recchia et al., 2015). This was regardless of tamoxifen use (Recchia et al., 2015).

\section{Survival and tumor response}

Following 96-weeks treatment with leuprorelin, the progression free survival was $50 \%$, and the recurrence free survival was 95\% (Lambertini et al., 2015). Similar disease free survival was observed in those treated with 6-monthly or 3-monthly injections (97\% and 98\%, respectively) (Ruddy et al., 2014). Distant disease free survival were reported.13 At week $96,15 \%$ of patient treated with leuprorelin achieved a best overall response (Lambertini et al., 2015).

\section{Adverse effects}

Typically, the majority of adverse effects are related to concomitant chemotherapy (GLOBOCAN, 2016). Women administered leuprorelin experienced grade 1 or 2 adverse events including hot flush, mood swings and urogenital symptoms (GLOBOCAN, 2016).

In the study comparing 3-monthly and 6-monthly injections, serious adverse events that were considered to be related to leuprorelin included interstitial lung disease $(\mathrm{n}=3)$ and anal fistula.

Adverse events associated with leuprorelin included injection site reactions, hot flushes, nasopharyngitis, radiation skin injury, decreased white blood cell counts, headache and arthralgia (Lambertini et al., 2015; Park 
Table 1. Studies of leuprorelin in Asian populations

\begin{tabular}{|c|c|c|c|c|c|c|}
\hline Study & Country & Population & Intervention & Comparator & Outcomes & Results \\
\hline $\begin{array}{l}\text { Song et at7 } \\
\text { RCT }\end{array}$ & China & $\begin{array}{l}\text { Premenopausal } \\
\text { women aged } 18-45 \\
\text { with stage I to III } \\
\text { breast cancer and } \\
\text { regular menstrual } \\
\text { cycle prior to study } \\
\text { entry } \\
n=183\end{array}$ & $\begin{array}{l}\text { Chemotherapy } \\
+ \text { leuprolide } \\
\text { acetate } 3.75 \\
\text { mg sc every } \\
\text { four weeks }\end{array}$ & $\begin{array}{l}\text { Chemotherapy } \\
\text { alone }\end{array}$ & $\begin{array}{l}\text { FSH levels; estradiol }\left(\mathrm{E}_{2}\right) \\
\text { levels; and menstrual } \\
\text { activity at } 3,6,9 \text { and } 12 \\
\text { months } \\
\text { Early menopause defined } \\
\text { as } \mathrm{FSH}>40 \mathrm{mIU} / \mathrm{mL} \\
\text { and } \mathrm{E}_{2}<20 \mathrm{pg} / \mathrm{mL} \text { in the } \\
\text { absence of resumption of } \\
\text { menstrual activity within } \\
12 \text { months after the end of } \\
\text { chemotherapy. } \\
\text { Effective treatment was } \\
\text { defined as resumption } \\
\text { of menstrual activity } \\
\text { (regardless of FSH level } \\
\text { or } \mathrm{E}_{2} \text { level) or occurrence } \\
\text { of FSH level } 40 \mathrm{mIU} / \mathrm{ml} \\
\text { and } \mathrm{E}_{2} \text { level[ } 20 \mathrm{pg} / \mathrm{ml} \text { in } \\
\text { the absence of resumption } \\
\text { of menstrual activity } \\
\text { during the } 12-\mathrm{month} \\
\text { follow-up after the end of } \\
\text { chemotherapy. }\end{array}$ & $\begin{array}{l}\text { Early menopause occurred in } 16.9 \% \\
\text { in the leuprolide-chemotherapy arm } \\
\text { and } 28.7 \% \text { in the chemotherapy } \\
\text { alone arm ( } \mathrm{p}<0.01) \text {. } \\
\text { Resumption of menses occurred } \\
\text { in } 60 \% \text { in the leuprolide- } \\
\text { chemotherapy arm and } 41 \% \text { in the } \\
\text { chemotherapy alone arm ( } \mathrm{p}<0.01 \text { ). } \\
\text { The median time to resumption } \\
\text { of menses was } 9.2 \text { months in the } \\
\text { leuprolide-chemotherapy arm and } \\
\text { not reached in the chemotherapy } \\
\text { alone arm. } \\
\text { Adverse effects were mostly related } \\
\text { to chemotherapy. In the leuprolide } \\
\text { group, patients reported hot flush, } \\
\text { mood swings, and urogenital } \\
\text { symptoms of Grade I or II. }\end{array}$ \\
\hline $\begin{array}{l}\text { Park et al12 } \\
\text { OL }\end{array}$ & Korea & $\begin{array}{l}\text { Women of } \\
\text { reproductive age } \\
\text { ( }<35 \text { years) with } \\
\text { adenocarcinoma } \\
\text { of the breast stage } \\
\text { I to III } \\
\mathrm{N}=22\end{array}$ & $\begin{array}{l}\text { Chemotherapy } \\
+ \text { leuprorelin } \\
3.75 \mathrm{mg} \mathrm{sc}\end{array}$ & - & $\begin{array}{l}\text { Hormone levels at } \\
1,3 \text { and } 6 \text { months } \\
\text { after completion of } \\
\text { chemotherapy }\end{array}$ & $\begin{array}{l}\text { Mean serum levels of FSH and LH } \\
\text { were similar to baseline } 6 \text { months } \\
\text { after completion of chemotherapy }\end{array}$ \\
\hline $\begin{array}{l}\text { Takeda } 10 \\
\text { NCT02154139 } \\
\text { OL }\end{array}$ & Japan & $\begin{array}{l}\text { Premenopausal } \\
\text { women with breast } \\
\text { cancer } \\
\mathrm{N}=644\end{array}$ & $\begin{array}{l}\text { Leuprorelin } \\
11.25 \mathrm{mg} \mathrm{sc} \\
\text { three monthly } \\
\text { for } 96 \text { weeks }\end{array}$ & & $\begin{array}{l}\text { Adverse events, best } \\
\text { response, progression free } \\
\text { survival (PFS), recurrence } \\
\text { free survival }\end{array}$ & $\begin{array}{l}128 \text { patients reported adverse } \\
\text { events, and there were } 20 \text { serious } \\
\text { adverse events. } \\
\text { Best overall response at week } 96 \text { : } \\
15 \% \\
\text { PFS at week } 96: 50 \% \\
\text { RFS at week } 96: 95 \%\end{array}$ \\
\hline $\begin{array}{l}\text { Kurebayashi } \\
\text { et all1 } \\
\text { RCT }\end{array}$ & Japan & $\begin{array}{l}\text { Premenopausal } \\
\text { women with } \\
\text { estrogen receptor } \\
\text { positive or } \\
\text { progesterone } \\
\text { receptor positive } \\
\text { breast cancer } \\
\mathrm{N}=150\end{array}$ & $\begin{array}{l}\text { Leuprorelin } \\
22.5 \mathrm{mg} \\
24 \text {-weekly sc } \\
\text { for up to } 96 \\
\text { weeks }\end{array}$ & $\begin{array}{l}\text { Leuprorelin } \\
11.25 \mathrm{mg} \\
12 \text {-weekly sc } \\
\text { for up to } 96 \\
\text { weeks }\end{array}$ & $\begin{array}{l}\text { Hormone levels, disease } \\
\text { free survival, distant } \\
\text { disease free survival, } \\
\text { serum levels, QT interval }\end{array}$ & $\begin{array}{l}\text { Menopausal levels of E2 were } \\
\text { achieved in both a 6-monthly and } \\
\text { 3-monthly arms ( } 98 \% \text { vs } 96 \% \text { ). } \\
\text { LH and FSH suppressed to } \leq 1 \text { and } \\
\leq 2.5 \mathrm{mIU} / \mathrm{mL} \text {, respectively from } \\
\text { week } 4 \text { and remained low through } \\
\text { to week } 96 \text {. } \\
\text { DFS at week } 96 \text { : } 97 \% \text { and } 98 \% \\
\text { (6-monthly and 3-monthly, } \\
\text { respectively). } \\
\text { DDFS at week } 96: 99 \% \text { and } \\
\text { 99\% (6-monthly and 3-monthly, } \\
\text { respectively). }\end{array}$ \\
\hline
\end{tabular}

$\mathrm{E}_{2}$, estradiol; OL, open-label; RCT, randomized controlled trial; sc, subcutaneous

et al., 2010). Injection site swelling is more common in patients receiving 6-monthly injections (Park et al., 2010).

Following administration of leuprorelin, QT correction formula (QTcF) intervals declined for the first six hours, and prolonged QTcF intervals of 10 milliseconds were observed from week 4 to 96 following both 3-monthly and 6-monthly injections (Park et al., 2010). Reductions in bone mineral density of approximately $8 \%$ were observed over the 96 week treatment period (Park et al., 2010).

\section{Discussion}

Leuprorelin is a synthetic analogue of naturally occurring gonadotropin-releasing hormone, a potent inhibitor of pituitary gonadotropin secretion when given continuously at therapeutic doses. Leuprorelin increases circulating levels of luteinizing hormone and follicle-stimulating hormone, leading to a transient increase in levels of the gonadal steroids (testosterone and dihydrotestosterone in males, and estrone and estradiol [E2] in premenopausal females). However, continuous administration of leuprorelin results in decreased levels of $\mathrm{LH}$ and $\mathrm{FSH}$, and reduces testosterone levels to below the castrate threshold in males $(\leq 50 \mathrm{ng} / \mathrm{dL})$, usually within 2 to 4 weeks from initiation of treatment.

To date, only four studies have reported data on leuprorelin use in Asian women with breast cancer. Of these, only three have been published. Two were conducted in Japan, (Lambertini et al., 2015; Park et al., 2010) one in Korea (Recchia et al., 2015) and one in China (GLOBOCAN, 2016). Leuprorelin was administered every 4 weeks (3.75 mg) (GLOBOCAN, 2016; Recchia et al., 2015), every 12-weeks, (Lambertini et al., 2015; Park et al., 2010) or every 24-weeks (Park et al., 2010). 
In all of the studies, leuprorelin was administered either with adjuvant chemotherapy or hormonal therapy. Only one study was randomized against a non-leuprorelin arm (GLOBOCAN, 2016).

In women with hormone sensitive cancers, suppression of estrogen may lead to prolonged disease-free survival in premenopausal women (Song et al., 2016; Virani et al., 2014). However, this is at the expense of fertility. Preservation of fertility is important to premenopausal women with malignant tumors (Wong et al., 2015). Traditional approaches to fertility preservation include cryopreservation of oocytes, fertilized embryos and ovarian tissue (Wong et al., 2015). GnRH agonists are recommended for premenopausal patients undergoing chemotherapy who wish to preserve ovarian function. 18 Importantly, women have been able to become pregnant and have successful pregnancy outcomes following surgery, chemotherapy and leuprorelin treatment.

Others have reported success treating patients with luteinizing hormone releasing hormone analogues in women who are premenopausal with breast cancer (Zhang et al., 2017). Treatment with luteinizing hormone releasing hormone analogues also appeared to improve the expected disease-free survival and overall survival (Zhang et al., 2017). Despite this, extended therapy with a GnRH agonist is not without difficulty, as extended therapy may not be acceptable to some women due to the side effects of treatment (such as hot flushes, vaginal dryness and pain (Zhou et al., 2015).

There are several limitations to our review. While the approach to the literature retrieval was systematic, we only included studies that were published in English, which may bias the results, particularly when considering the fact that we are focusing on an Asian population. Secondly, limited statistical analyses were provided for the two unpublished studies (Lambertini et al., 2015; Ruddy et al., 2014), One study has subsequently been published, and is included (Park et al., 2010).

In conclusion, a limited number of studies have investigated leuprorelin for the treatment of patients with breast cancer in Asia. In these studies, leuprorelin was shown to preserve ovarian function, reduce symptoms of ovarian failure, reduce the occurrence of early menopause as well as time to resumption of menses, and reduce E2 concentrations to menopausal levels.

\section{Funding}

Editorial support for the development of this article was provided by MediTech Media Asia Pacific; this support was funded by Takeda Pharmaceuticals (Asia Pacific) Pte. Ltd.

\section{Conflict of interest declaration}

HJY and WH have no conflicts of interest to declare.

\section{Acknowledgements}

Medical writing services provided by Dr Belinda Butcher CMPP from WriteSource Medical Pty Ltd were funded by Takeda in accordance with Good Publication Practice (GPP3) guidelines (http://ismpp.org/gpp3).

\section{References}

Asthana S, Chauhan S, Labani S (2014). Breast and cervical cancer risk in India: An Update. Indian J Public Health, 58, 5-10.

Ataya K, Rao LV, Lawrence E, Kimmel R (1995). Luteinizing hormone-releasing hormone agonist inhibits cyclophosphamide-induced ovarian follicular depletion in Rhesus Monkeys. Biol Reprod, 52, 365-72.

Bokser L, Szende B, Schally AV (1990). Protective effects of D-Trp6-Luteinising hormone-releasing hormone microcapsules against cyclophosphamide-induced gonadotoxicity in female Rats. Br J Cancer, 61, 861-5.

ClinicalTrials.gov. A PHASE 3 COMPARATIVE STUDY OF TAP-144-SR(6M) IN Postoperative and Hormone Therapy-Naïve Patients with Premenopausal Breast Cancer. NCT01546649. Accessed via https://clinicaltrials.gov/ct2/ show/study/NCT01546649? term $=\mathrm{A}+\mathrm{Phase}+3+$ Comparativ e+Study+of+TAP-144-SR\%286M\%29+in+Postoperative+ and+Hormone+Therapy-naïve+Patients+With+Premenopa usal+Breast + Cancer\&rank=1. Accessed 1 November 2017 .

ClinicalTrials.gov. Leuprorelin Acetate $\mathrm{Sr} 11.25 \mathrm{Mg}$ For Injection Specified Drug-Use Survey "Long-Term Use Survey On Premenopausal Breast Cancer Patients (96 WEEKS). NCT02154139. Accessed via https:// clinicaltrials.gov/ct2/show/results/NCT02154139? term=NCT02154139\&rank=1. Accessed 1 November 2017.

Francis PA, Regan MM, Fleming GF, et al (2015). Adjuvant ovarian suppression in premenopausal breast cancer. $N E n g l$ J Med, 372, 436-46.

International Agency for Research on Cancer. GLOBOCAN CANCER FACT SHEETS: BREAST CANCER. Accessed via http://globocan.iarc.fr/old/FactSheets/ cancers/breast-new.asp. Accessed July 2016.

Kim J, Kim M, Lee JH, et al (2014). Ovarian function preservation with Gnrh agonist in young breast cancer patients: Does it impede the effect of adjuvant chemotherapy?. Breast $J$, 23, 670-5.

Kurebayashi J, Toyama T, Sumino S, Miyajima E, Fujimoto T (2017). Efficacy and safety of Leuprorelin Acetate 6-Month Depot, Tap-144-Sr (6m), in combination with Tamoxifen in postoperative, premenopausal patients with hormone receptor-positive breast cancer: A phase Iii, randomized, open-label, parallel-group comparative study. Breast Cancer, 24, 161-70.

Lambertini M, Ceppi M, Poggio F, et al (2015). Ovarian suppression using luteinizing hormone-releasing hormone agonists during chemotherapy to preserve ovarian function and fertility of breast cancer patients: A meta-analysis of randomized studies. Ann Oncol, 26, 2408-19.

Park HJ, Koo YA, Im YH, Yoon BK, Choi D (2010). Gnrh agonist therapy to protect ovarian function in young Korean breast cancer patients. J Korean Med Sci, 25, 110-6.

Recchia F, Candeloro G, Rosselli M, et al (2015). Adjuvant ovarian suppression, high-dose chemotherapy and immunotherapy for premenopausal patients with high-risk breast cancer. Anticancer Res, 35, 6847-53.

Ruddy KJ, DeSantis SD, Barry W, et al (2014). Extended therapy with Letrozole and ovarian suppression in premenopausal patients with breast cancer afterTamoxifen. Clin Breast Cancer, 14, 413-6.

Song G, Gao H, Yuan Z (2013). Effect of Leuprolide Acetate on ovarian function after Cyclophosphamide-Doxorubicinbased Chemotherapy in Premenopausal patients with breast cancer: Results from a phase Ii randomized trial. Med Oncol, 30, 667.

Stachs A, Hartmann S, Gerber B (2017). Preservation of 
fertility or ovarian function in patients with breast cancer or gynecologic and internal malignancies. Geburtshilfe Frauenheilkd, 77, 861-69.

Virani S, Sriplung H, Rozek LS, Meza R (2014). Escalating burden of breast cancer in Southern Thailand: Analysis of 1990-2010 incidence and prediction of future trends. Cancer Epidemiol, 38, 235-43.

Wong IO, Schooling CM, Cowling BJ, Leung GM (2015). Breast cancer incidence and mortality in a transitioning Chinese population: Current And Future Trends. Br J Cancer, 112, 167-70.

Wu LZ, Han RQ, Zhou JY, et al (2014). Incidence and mortality of female breast cancer in Jiangsu, China. Asian Pac J Cancer Prev, 15, 2727-32.

Zhang P, Li CZ, Jiao GM, et al (2017). Effects of ovarian Ablation or suppression in premenopausal breast cancer: A meta-analysis of randomized controlled trials. Eur J Surg Oncol, 43, 1161-72.

Zhou HB, Liu SY, Lei L, et al (2015). Spatio-temporal analysis of female breast cancer incidencein Shenzhen, 2007-2012. Chin J Cancer, 34, 198-204.

\section{c) (i) (8)}

This work is licensed under a Creative Commons AttributionNon Commercial 4.0 International License. 